\title{
Microfinance - One of the Key Drivers of Financial Inclusion in Nigeria
}

\author{
EJEFOBIHI, Ugochukwu Frank ${ }^{1}$, IMOAGWU, Chika Priscilla ${ }^{2}$, EZEANYEJI, Clement. I. PhD ${ }^{3}$
}

\author{
${ }^{1}$ Chukwuemeka Odumegwu Ojukwu University, Anambra State, Nigeria. \\ Email: lambatzfrank@gmail.com \\ ${ }^{2}$ Department of Economics, Nnamdi Azikiwe University, Anambra State, Nigeria. \\ chikaimoagwu@gmail.com
}

${ }^{3}$ Department of Economics, Faculty of Social Sciences, Chukwuemeka Odumegwu Ojukwu university, Anambra State, Nigeria. drsundayeze@gmail.com

\begin{abstract}
This study tries to establish the microfinance and financial inclusion nexus in Nigeria from 1981 to 2017. The Augmented Dickey-Fuller (ADF) test, co-integration test and Error Correction Model (ECM), as well as diagnostics and stability test were employed in the analysis. The research findings revealed that microfinance has positive significant effect on financial inclusion in Nigeria in the short-run and long-run. This finding is in line CBN objectives for the establishment of microfinance banks. The effect of lending interest rate has a positive but has no significant with financial inclusion in the model one while it is statistically significant with poverty in Nigeria in the mode two. The positive lending interest rate has a statistically significant effect on the level of financial inclusion and national poverty index used as a proxy for poverty rate in the long run in the models. Also, the research also found that microfinance has really a tool to fight against poverty in Nigeria in the short-run, while it's not really a tool to fight against poverty in the long-run in Nigeria. It was therefore recommended that Government agency and regulatory authority policies and practices need to play a key role in making micro-credit available to the economically-active poor people who are not being served by the formal financial sector. Also, apart from monitoring lending interest rates, the government needs to establish frameworks to prevent undercapitalization, fraudulent practices, and unwarranted interference from bank board members in Nigeria.
\end{abstract}

Keywords: Microfinance, financial inclusion, lending interest rate, loans and advances, national poverty index.

\subsection{INTRODUCTION}

It has been widely acknowledged that the primary goal of microfinance is to achieve favourable financial services in developed and developing economies, Nigeria inclusive. Financial inclusion may be defined as the process of ensuring access to financial services and timely and adequate credit where needed by vulnerable groups such as weaker sections and low income groups at an affordable cost (Ibeachu, 2010). The Center for Financial Inclusion (2013) refers financial inclusion as a state in which everyone who can use them has access to a full suite of quality financial services, provided at affordable prices, in a convenient manner, with respect and dignity. Financial services are delivered by a range of providers, in a stable, competitive market to financially capable clients. At its most basic level, financial inclusion starts with having a deposit or transaction account at a bank or other financial institution or through a mobile money service provider, which can be used to make and receive payments and to store or save money DemirgucKunt, Klapper \& Singer (2017).

However, according to Osamwonyi and Obayagbona (2012), microfinance literally means building financial systems that effectively and efficiently serve the needs of the poor. Microfinance is the provision of a broad range of financial services such as savings, loans, payment services, money transfers and insurance to the poor and low income persons, households and their micro enterprises. Roadman (2012) opines that microfinance bank is the provision of financial services to low income earners, including consumers and the self-employed who traditionally lack access to formal money deposit banking and related services. In other words, it is the provision of small loans (microcredit) to poor people to enable them engage in productive activities or grow their businesses.

Microfinance programmers are intended to reach poor segments of society as they lack access to financial services. It seeks to reach out to the excluded category of population from the banking system. Financial inclusion is not just credit dispensation; it is about connecting the people with the banking system for availing bouquet of financial services including access to payment system (Dwivedi, 2013).

Financial inclusion does not imply that everyone will use all available financial services; rather everyone has the option to use them. A continuum of financial services needs to be made accessible to individuals as they improve their standard of living. More recently, financial inclusion has been defined by the World Bank (2015), as the absence of price and nonprice barriers in the use of financial services. Financial inclusion can help reduce poverty and inequality by helping people invest in the future, smooth their consumption, and manage financial risks. Adults around the world and in all income groups use an array of different financial services. However, many low-income adults rely on informal financial 
services (Collins, et al., 2009). Access to formal financial services allows people to make financial transactions more efficiently and safely and helps poor people climb out of poverty by making it possible to invest in education and business. By providing ways to manage income shocks like unemployment or the loss of a breadwinner, financial inclusion can also prevent people from falling into poverty in the first place. This is especially relevant for people living in the poorest households.

The relationship between microfinance and financial inclusion cannot be overemphasis because microfinance is one of the key drivers which affect the financial inclusion. Increased inclusion brings both efficiency and equity benefits. Microfinance is also revealing substantial commercial opportunities and attracting growing private capital flows. The essence of financial inclusion is in trying to ensure that a range of appropriate financial services is available to every individual and enabling them to understand and access those services. Apart from the regular form of financial intermediation, it may include a basic no frills banking account for making and receiving payments, a savings product suited to the pattern of cash flows of a poor household, money transfer facilities, small loans and overdrafts for productive, personal and other purposes, insurance (life and non-life), etc. It is therefore imperative to examine the microfinance and financial inclusion nexus in Nigeria.

\section{Objectives of the Study}

The broad purpose of the research paper is to demonstrate the effects of microfinance as a part of financial inclusion in Nigeria. Specifically, this study

1. To investigate the effect of microfinance on financial inclusion in Nigeria

2. To analyse the effect of lending interest rate on financial inclusion in Nigeria

3. To examine if microfinance has really a tool to fight against poverty in Nigeria.

\section{Research Questions}

The study seeks to therefore provide answers to the following questions

1. To what extent has microfinance affected financial inclusion in Nigeria?

2. Has lending interest rate affected financial inclusion in Nigeria?

3. Is microfinance really a tool to fight against poverty in Nigeria?

\subsection{REVIEW OF RELATED LITERATURE}

\subsection{Theoretical Review}

1. Information Asymmetry Theory
The theory of information asymmetry is often used to explain the financial constraints and exclusion small firms and poor borrowers encounter. Intermediation will ensure efficient allocation of financial resources when financial intermediaries can overcome the problems of information asymmetry (Hannig \& Jansen, 2010). Asymmetric information is the difference in information available to different parties in a financial contract (Brealey, Leland \& Pyle, 1977; Hannig \& Jansen, 2010; Sharpe, 1990). The theory suggests that information gaps exist between lenders and borrowers in a way that does not allow optimal allocation and utilisation of financial resources. This information imbalance occurs because borrowers often tend to have informational advantage over lenders. Borrowers know more about the investment projects they want to undertake, the risk involved and their own risk behaviour. This information may not be fully disclosed when entering contractual engagements and therefore gives rise to this imbalance (Brealey, et al., 1977; Hannig \& Jansen, 2010; Sharpe, 1990).

\section{Transaction Cost Theory}

Transaction cost theory in lending, pioneered by Scholes, Benston, and Smith (1976) and later Campbell and Kracaw (1982), is based on the notion that market friction and imperfection warrant the existence of financial intermediaries (Kwakye, 2012; Scholtens \& van Wensveen, 2003). The theory posits that by acting as coalitions of either borrowers or lenders, scale economies in transaction technologies could be exploited (Kwakye, 2012; Scholes, et al., 1976; Scholtens \& van Wensveen, 2003). The concept of transaction cost helps to partly explain why formal financial intermediaries are reluctant to provide financial services to poor households and small firms. The small nature of transactions involved makes it costly and unprofitable to serve small borrowers at the going interest rates (Beck \& Demirgüç-Kunt, 2008; Beck, et al., 2009; Johnston \& Morduch, 2008).

Regulation becomes necessary where the socio-economic cost of market failure outweighs the private and marginal costs of regulation (Brunnermeier, Crockett, Goodhart, Persaud, \& Shin, 2009). In the financial services industry, it is argued that regulation guarantees soundness and safety for all the market actors (Boot \& Thakor, 1993; Scholtens \& van Wensveen, 2003). The solvency and liquidity position of the financial inclusions are altered through regulation. For instance, regulation that imposes huge minimum capital requirements limit sentry into the industry as it also ensures the intermediaries' safety and their ability to refinance (Diamond \& Rajan, 2000). According to Kwakye (2012), regulation is needed to check on the potentially insidious behaviour of banks, such as collusive tendencies, which may affect the price clients pay. This further ensures that banks deal with customers fairly in respect of interest offered on deposits and interest charged to borrowers. Thus, to ensure sustained public confidence, interest and patronage that 
prevents bank run or failure, regulation becomes inevitable for the financial inclusion existence (Greenbaum, et al., 2015).

\subsection{Issues and Challenges}

1. The vast segments of population particularly poor segment of society are not of the formal financial system. The financial inclusion process should take the banking services to the poor rather than poor people coming to the bank for availing the services.

2. For sustaining the financial inclusion, the financial literacy becomes a very critical component. There is a need to simultaneously focus on the financial literacy part besides the delivery or access.

3. Penetration of insurance services - issuance services largely remain as the urban phenomena. It should reach out to the rural and remote areas and to the poor segments of the societies. Micro insurance services should be given greater importance while extending the financial services.

4. Cost effective technologies and applications in appropriate manner.

5. Access to payment services through technology.

6. Regional imbalances in the financial inclusion process are quite visible and there is a need for the microfinance movement to the broad based in Nigeria to make the financial inclusion more meaningful and inclusive.

\subsection{Types of Microfinance}

The figure 2.1 below presents types of microfinance used by poor

people.

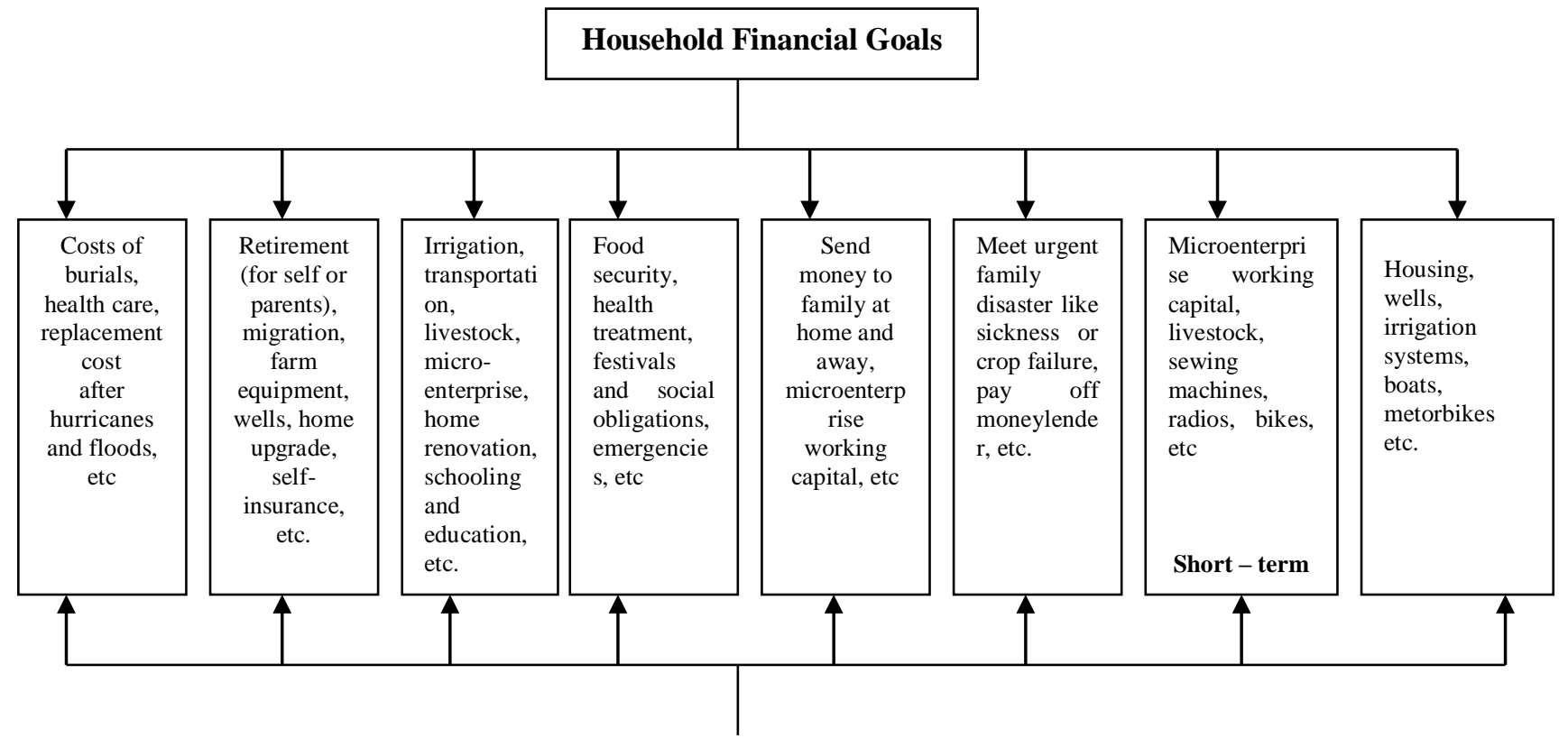

Microfinance Products

The poor people borrow from informal moneylenders and save with informal collectors. They receive loans and grants from charities. They buy insurance from state-owned companies. They receive funds transfers through formal or informal remittance networks. It is not easy to distinguish microfinance from similar activities. It could be claimed that a government that orders state banks to open deposit accounts for poor consumers, or a moneylender that engages in usury, or a charity that runs a heifer pool are engaged in microfinance (Dwivedi, 2013).

Some principles that summarize a century and a half of development practice were encapsulated in 2004 by consultative Group to Assist the poor (CGAP) and endorsed by group of Eight leaders at the G8 summit on June 10, 2004 are follows:
1. Poor people need not just loans but also savings, insurance and money transfer services.

2. Microfinance must be useful to poor households helping them raise income, build up assets and/or cushion themselves against external shocks.

3. Microfinance can pay for itself. Subsides from donors and government are scare and uncertain, and so to reach large numbers of poor people.

4. Microfinance means building permanent local institutions.

5. Microfinance also means integrating the financial needs of poor people into a country's mainstream financial system.

6. The job of government is to enable financial services, not to provide them. 
7. Donor funds should complement private capital, not compete with it.

8. "The key bottleneck is the shortage of strong institutions and managers". Donors should focus on capacity building.

9. Microfinance institutions should measure and disclose their performance - both financially and socially.

However, microfinance is clearly distinguishable from charity. Families who are destitute, or so poor they are unlikely to be able to generate the cash flow required to repay a loan, should be recipients of charity. Others are best served by financial institutions.

\subsection{Empirical Literature}

A vast amount of empirical literature has been conducted within and across the countries to reveal whether microfinance has a significant impact on financial inclusion. For instance, Atiase, Wang and Mahmood (2019) focused on the impact of microcredit provided by FNGOs on employment growth among MSEs in Ghana. The study employed primary data collected from 506 MSEs in Ghana using sampling technique and Ordinary Least Squares for the analysis. The research results showed that microcredit which is flexible in repayment mode, accessible and adequate has a positive impact on employment generation among MSEs in Ghana. However, the current cost of microcredit in Ghana has a negative impact on employment growth among MSEs.

Ananwude, Anyanwu and Andrew (2018) curtained on the significant effectiveness of Nigeria's microfinance model of financial inclusion on women empowerment. A descriptive survey design and Ordinary Least Squares was utilized in the analysis. Two hundred (200) questionnaires were distributed to respondents, out of which one hundred and ninety (190) were fully completed and used for the analysis. The research finding revealed identified a positive and significant relationship between women empowerment and microfinance banks' products: rent savings, child education, new born and daily savings account.

Using the fully modified OLS (FMOLS) and the Dynamic OLS (DOLS), Adeola and Olaniyi (2017) undertook the impact of microfinance on financial inclusion in Nigeria. The study employed total commercial banks' loans and advances, number of microfinance banks in Nigeria, and gross domestic product (GDP) as well as lending interest rates from 1981 to 2014 . The research finding revealed that microfinance and financial inclusion are linked by a set of long-run relationships. In the short run, the study found that microfinance has a positive but insignificant impact on financial inclusion, but in the long run, microfinance has a positive and statistically significant impact on the level of financial inclusion. The negative interest rate has a statistically significant impact on the level of financial inclusion both in the short and long run.

Employing annual data over the period 1981-2014 and the ARDL bounds testing approach, Olaniyi (2017) focused on the long run as well as the short-run dynamics of the relationship between financial inclusion and agriculture in Nigeria. The research findings revealed that usage of financial services has significant impacts on agriculture both in the short and the long run, meaning that for sustainable agricultural development in rural areas, improving financial inclusion is critical. Also, the access to finance has insignificant impacts on agricultural growth. Similarly, using Augmented Dickey-Fuller Unit Root test, Johansen cointegration test and Error Correction Model (ECM) for the analysis, Usifoh and Ezeanyeji (2017) explored the microfinance banks as a panacea for poverty alleviation and economic growth in Nigeria from $1992-2016$. The research findings show that the asset of microfinance has significant effect on poverty alleviation and economic growth in Nigeria; deposit liabilities of microfinance banks have positive but insignificant effect on poverty alleviation and economic growth in Nigeria; and loans and advances of microfinance banks have negative significant effect on poverty alleviation and economic growth in Nigeria. Furthermore, the overall significance of the model found that the activities of the microfinance banks cannot be undermined in the pursuance of poverty alleviation and sustainable economic growth in Nigeria.

Finally, Ene and Inemesit (2015) undertook the impact of microfinance in promoting financial inclusion in Nigeria between 1990 and 2014 using Augmented Dickey-Fuller (ADF) unit root test, Johansen co-integration test and Ordinary Least Square (OLS) method for the analysis. The research findings indicated that minimum deposit amount have a positive and significant relationship with saving. It was also revealed that access to microfinance minimum deposit amount has significant effect on savings account opened by rural dwellers. Furthermore, microfinance interest rate was however found to have a negative and insignificant relationship with the rural dwellers loans and advances. Similarly, Ezeanyeji and Ozughalu (2014) highlighted some major conceptual, theoretical and mythological issues, and it reflects on the poverty and competitive situation in Nigeria. The study employs verbal constructs and tabular presentations in its exposition in the analysis. The research findings pointed out that Nigeria is plagued with pervasive poverty, high level of underdevelopment, poor performance of the manufacturing sector and poor level of competitiveness, among others. The summary of recent related empirical literature on the subject which was reviewed to provide evidence of studies on related areas is presented in table 2.1 below. 
International Journal of Academic Accounting, Finance \& Management Research (IJAAFMR)

Vol. 3 Issue 5, May - 2019, Pages: 1-15

Table 2.1: Tabular summary of reviewed literature

\begin{tabular}{|c|c|c|c|c|c|c|c|}
\hline \multirow[t]{2}{*}{$\mathrm{S} / \mathrm{No}$} & \multirow{2}{*}{$\begin{array}{l}\text { Author(s)/ } \\
\text { Years }\end{array}$} & \multicolumn{5}{|c|}{ Methodology } & \multirow[t]{2}{*}{ Research Findings } \\
\hline & & $\begin{array}{l}\text { Period of } \\
\text { Study }\end{array}$ & $\begin{array}{l}\text { Location } \\
\text { of Study }\end{array}$ & Research Topic & $\begin{array}{l}\text { Variables of } \\
\text { the Model }\end{array}$ & $\begin{array}{l}\text { Method of } \\
\text { Analysis }\end{array}$ & \\
\hline 1. & $\begin{array}{l}\text { Atiase, } \\
\text { Wang \& } \\
\text { Mahmood } \\
(2019)\end{array}$ & 506 MSEs & Ghana & $\begin{array}{l}\text { FNGOs and } \\
\text { financial } \\
\text { Inclusion: } \\
\text { Investigating } \\
\text { the impact of } \\
\text { Microcredit on } \\
\text { Employment } \\
\text { Growth in } \\
\text { Ghana }\end{array}$ & - & $\begin{array}{l}\text { Sampling } \\
\text { technique and } \\
\text { Ordinary } \\
\text { Least Squares }\end{array}$ & $\begin{array}{l}\text { The research } \\
\text { results showed that } \\
\text { microcredit which } \\
\text { is flexible in } \\
\text { repayment mode, } \\
\text { accessible and } \\
\text { adequate has a } \\
\text { positive impact on } \\
\text { employment } \\
\text { generation among } \\
\text { MSEs in Ghana. } \\
\text { However, the } \\
\text { current cost of } \\
\text { microcredit in } \\
\text { Ghana has a } \\
\text { negative impact on } \\
\text { employment } \\
\text { growth among } \\
\text { MSEs }\end{array}$ \\
\hline 2. & $\begin{array}{l}\text { Ananwude, } \\
\text { Anyanwu, \& } \\
\text { Andrew } \\
(2018)\end{array}$ & $\begin{array}{l}\text { Two hundred } \\
(200) \\
\text { questionnaires }\end{array}$ & Nigeria & $\begin{array}{l}\text { Financial } \\
\text { Inclusion: } \\
\text { Nigeria's } \\
\text { Microfinance } \\
\text { Model Effect } \\
\text { Assessment on } \\
\text { Women } \\
\text { Empowerment }\end{array}$ & $\begin{array}{l}\text { Women } \\
\text { empowerment } \\
\text { and } \\
\text { microfinance } \\
\text { banks' } \\
\text { products: rent } \\
\text { savings, child } \\
\text { education, new } \\
\text { born and daily } \\
\text { savings } \\
\text { account }\end{array}$ & $\begin{array}{l}\text { Yaro-Yamani } \\
\text { sampling } \\
\text { technique and } \\
\text { Ordinary } \\
\text { Least Squares }\end{array}$ & $\begin{array}{l}\text { The research } \\
\text { finding revealed } \\
\text { identified } \\
\text { positive and } \\
\text { significant } \\
\text { relationship } \\
\text { between women } \\
\text { empowerment and } \\
\text { microfinance } \\
\text { banks products: } \\
\text { rent savings, child } \\
\text { education, new } \\
\text { born and daily } \\
\text { savings account }\end{array}$ \\
\hline 3. & $\begin{array}{l}\text { Adeola } \quad \& \\
\text { Olaniyi } \\
(2017)\end{array}$ & $1981-2014$ & Nigeria & $\begin{array}{l}\text { The Impact of } \\
\text { Microfinance } \\
\text { on } \\
\text { Financial } \\
\text { Inclusion in } \\
\text { Nigeria }\end{array}$ & $\begin{array}{l}\text { Total } \\
\text { commercial } \\
\text { banks' loans } \\
\text { and advances, } \\
\text { number of } \\
\text { microfinance } \\
\text { banks in } \\
\text { Nigeria, and } \\
\text { gross domestic } \\
\text { product (GDP) } \\
\text { as well as } \\
\text { lending } \\
\text { interest rates }\end{array}$ & $\begin{array}{l}\text { Fully } \\
\text { modified OLS } \\
\text { (FMOLS) and } \\
\text { the Dynamic } \\
\text { OLS (DOLS) }\end{array}$ & $\begin{array}{l}\text { The research } \\
\text { finding revealed } \\
\text { that microfinance } \\
\text { and financial } \\
\text { inclusion are linked } \\
\text { by a set of long-run } \\
\text { relationships. In } \\
\text { the short run, the } \\
\text { study found that } \\
\text { microfinance has a } \\
\text { positive but } \\
\text { insignificant } \\
\text { impact on financial } \\
\text { inclusion, but in } \\
\text { the long run, } \\
\text { microfinance has a } \\
\text { positive and } \\
\text { statistically } \\
\text { significant impact }\end{array}$ \\
\hline
\end{tabular}




\begin{tabular}{|c|c|c|c|c|c|c|c|}
\hline & & & & & & & $\begin{array}{l}\text { on the level of } \\
\text { financial inclusion. } \\
\text { The negative } \\
\text { interest rate has a } \\
\text { statistically } \\
\text { significant impact } \\
\text { on the level of } \\
\text { financial inclusion } \\
\text { both in the short } \\
\text { and long run }\end{array}$ \\
\hline 4. & $\begin{array}{l}\text { Olaniyi } \\
(2017)\end{array}$ & $1981-2014$ & Nigeria & $\begin{array}{l}\text { Back to the } \\
\text { Land: } \\
\text { Impact the } \\
\text { Financial } \\
\text { Inclusion of } \\
\text { Agriculture in } \\
\text { Nigeria }\end{array}$ & $\begin{array}{l}\text { Agriculture } \\
\text { share of GDP, } \\
\text { lending } \\
\text { interest rate, } \\
\text { broad money, } \\
\text { GDP per } \\
\text { capita, number } \\
\text { of commercial } \\
\text { bank branches } \\
\text { per } 1000 \mathrm{~km} 2 \\
\text { and } \\
\text { outstanding } \\
\text { loans from the } \\
\text { financial sector } \\
\text { to the } \\
\text { agricultural } \\
\text { sectoras \% of } \\
\text { GDP. }\end{array}$ & $\begin{array}{l}\text { ARDL } \\
\text { bounds } \\
\text { testing } \\
\text { approach }\end{array}$ & $\begin{array}{l}\text { The research } \\
\text { findings revealed } \\
\text { that usage of } \\
\text { financial services } \\
\text { has significant } \\
\text { impacts on } \\
\text { agriculture both in } \\
\text { the short and the } \\
\text { long run, meaning } \\
\text { that for sustainable } \\
\text { agricultural } \\
\text { development in } \\
\text { rural areas, } \\
\text { improving } \\
\text { financial inclusion } \\
\text { is critical. Also, the } \\
\text { access to finance } \\
\text { has insignificant } \\
\text { impacts on } \\
\text { agricultural growth }\end{array}$ \\
\hline 5 . & $\begin{array}{l}\text { Usifoh \& } \\
\text { Ezeanyeji } \\
(2017)\end{array}$ & $1992-2016$ & Nigeria & $\begin{array}{l}\text { Impact of } \\
\text { Microfinance } \\
\text { Banks on } \\
\text { Poverty } \\
\text { Alleviation and } \\
\text { Economic } \\
\text { Growth } \\
\text { Nigeria }\end{array}$ & $\begin{array}{l}\text { Real Gross } \\
\text { Domestic } \\
\text { Product } \\
\text { proxied by } \\
\text { economic } \\
\text { growth, } \\
\text { Poverty rate, } \\
\text { assets of } \\
\text { microfinance } \\
\text { bank, } \\
\text { deposit } \\
\text { Liabilities of } \\
\text { microfinance } \\
\text { bank, and } \\
\text { loans and } \\
\text { advances of } \\
\text { microfinance } \\
\text { banks }\end{array}$ & $\begin{array}{l}\text { Augmented } \\
\text { Dickey-Fuller } \\
\text { Unit Root } \\
\text { test, Johansen } \\
\text { cointegration } \\
\text { test and Error } \\
\text { Correction } \\
\text { Model (ECM) }\end{array}$ & 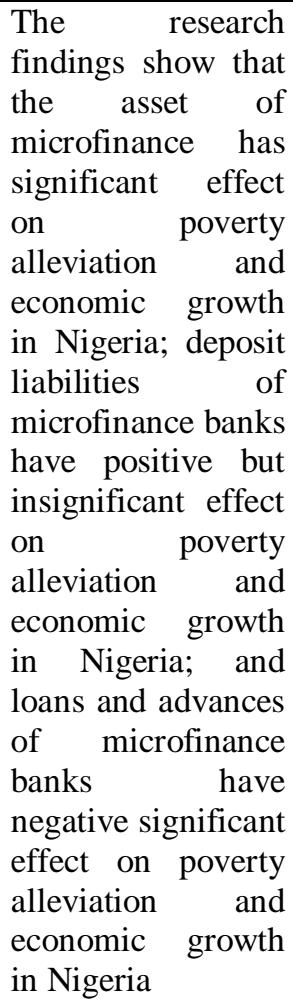 \\
\hline 6. & Ene & $1990-2014$ & Nigeria & Impact & Loans & Augmented & The research \\
\hline
\end{tabular}




\begin{tabular}{|c|c|c|c|c|c|c|c|}
\hline & $\begin{array}{l}\text { Inemesit } \\
(2015)\end{array}$ & & & $\begin{array}{l}\text { Microfinancein } \\
\text { Promoting } \\
\text { Financial } \\
\text { Inclusion in } \\
\text { Nigeria }\end{array}$ & $\begin{array}{l}\text { advances, } \\
\text { Interest rate, } \\
\text { savings } \\
\text { accounts, } \\
\text { Minimum } \\
\text { Deposit } \\
\text { Amount, }\end{array}$ & $\begin{array}{l}\text { Dickey-Fuller } \\
(\text { ADF) unit } \\
\text { root test, } \\
\text { Johansen co- } \\
\text { integration } \\
\text { test and } \\
\text { Ordinary } \\
\text { Least Square } \\
\text { (OLS) method }\end{array}$ & 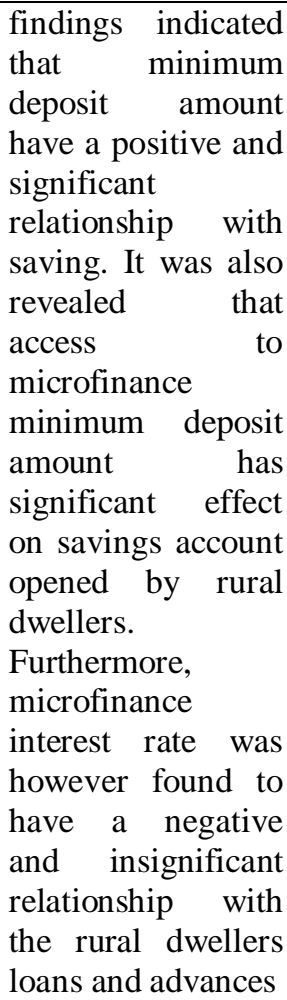 \\
\hline 7. & $\begin{array}{l}\text { Ezeanyeji \& } \\
\text { Ozughalu } \\
(2014)\end{array}$ & - & Nigeria & $\begin{array}{l}\text { Conceptual and } \\
\text { Theoretical } \\
\text { Issues in } \\
\text { Poverty, and a } \\
\text { Reflection on } \\
\text { the Poverty and } \\
\text { Competitive } \\
\text { Situation in } \\
\text { Nigeria }\end{array}$ & - & $\begin{array}{l}\text { Verbal } \\
\text { constructs and } \\
\text { tabular } \\
\text { presentations }\end{array}$ & $\begin{array}{l}\text { The research } \\
\text { findings pointed } \\
\text { out that Nigeria is } \\
\text { plagued with } \\
\text { pervasive poverty, } \\
\text { high level of } \\
\text { underdevelopment, } \\
\text { poor performance } \\
\text { of the } \\
\text { manufacturing } \\
\text { sector and poor } \\
\text { level of } \\
\text { competitiveness, } \\
\text { among others }\end{array}$ \\
\hline
\end{tabular}

Source: Author's Compilation, 2019.

\subsection{Literature Gap}

From the above peruse literature review, it could be seen as little studies have been conducted in Nigeria and outside regarding the effect of microfinance on financial inclusion in Nigeria. To the best of the researcher's knowledge from the empirical literature reviewed, no study has ever sought to establish the econometric analysis of the investigate the effect of microfinance and lending interest rate on financial inclusion and also examine if microfinance has really a tool to fight against poverty in Nigeria from the period of 1981 to 2017 using more robust econometric techniques such as, Augmented Dickey-Fuller (ADF), co-integration test and Error Correction Model (ECM), as well as diagnostics and stability test. In view of this problem in mind, thus this study is justified based on the identified research gaps.

\subsection{RESEARCH METHODOLOGY Model Specifications}

Model I:

The model one (1) adopted for this study is derived from the previous study carried out by Adeola and Olaniyi (2017) with some modifications to capture objective one (1) of this study. Interest rate is one of the most important variables when considering micro-credit, therefore the lending interest rate, money supply, and inflation rate are included as a control variable. This is, as well, to preclude the omitted variable bias. The functional form of the model is therefore specified as follows;

$\mathrm{FI}=\mathrm{f}(\mathrm{LA}, \mathrm{MS}, \mathrm{LR}, \mathrm{INF})$

The econometric form of the model can be expressed as: 
$\mathrm{FI}=\alpha_{0}+\alpha_{1} \mathrm{LA}+\alpha_{2} \mathrm{MS}+\alpha_{3} \mathrm{LR}+\alpha_{4} \mathrm{INF}+\mu_{\mathrm{t}}-\cdot-\cdot-\cdot-\cdot-\cdot-$ $-(3.2)$

The linearized form of equation of equation (3.2) is gotten by taking logarithms which is then specified as:

$\mathrm{LnFI}_{\mathrm{t}}=\alpha_{0}+\alpha_{1} \mathrm{LnLA}_{\mathrm{t}}+\alpha_{2} \mathrm{MS}_{\mathrm{t}}+\alpha_{3} \mathrm{LR}_{\mathrm{t}}+\alpha_{4} \mathrm{INF}_{\mathrm{t}}+\mu_{\mathrm{t}}$ $(3.3)$

Where;

LnFI = Commercial bank deposit used as a proxy for financial inclusion.

LnLA = Loans and advances of microfinance banks

MS = Money supply measures as percentage of GDP

$\mathrm{LR}=$ Lending interest rate

$\mathrm{INF}=$ Inflation rate

$\alpha_{0}=$ Constant

$\alpha_{1}-\alpha_{4}=$ Estimation parameters

$\mu_{\mathrm{t}}=$ Stochastic error term incorporated in any regression model based on the classical assumption of a linear regression model to account for variables omitted in the model

$\mathrm{Ln}=$ Natural logarithm of the variables used to smoothen possible scholastic effect from variables at level

$\mathrm{t}=$ Time period

It is expected that $\alpha_{1}>0, \alpha_{2}>0, \alpha_{3}>0$, and $\alpha_{4}>0$. However, if the estimates of the parameters turn up with signs or size not conforming to economic theory, they would be rejected, unless there is a good reason to believe that in the particular instance, the principles of economic theory do not hold.

\section{Model II:}

The model two (2) is expected to capture objective two (2) of the study, which is to examine if microfinance has really a tool to fight against poverty in Nigeria. The model adopted for this study is derived from the previous study carried out by Usifoh and Ezeanyeji (2017) with some modifications. Interest rate is one of the most important variables when considering micro-credit, therefore the lending interest rate, money supply, and inflation rate are included as a control variable. This is, as well, to preclude the omitted variable bias. The functional form of the model is therefore specified as follows;

$\mathrm{NPI}=\mathrm{f}(\mathrm{LA}, \mathrm{MS}, \mathrm{LR}, \mathrm{INF})$

The econometric form of the model can be expressed as: $\mathrm{NPI}=\beta_{0}+\beta_{1} \mathrm{LA}+\beta_{2} \mathrm{MS}+\beta_{3} \mathrm{LR}+\beta_{4} \mathrm{INF}+\mu_{\mathrm{t}}$ $-(3.5)$

The linearized form of equation of equation (3.5) is gotten by taking logarithms which is then specified as:

$\mathrm{NPI}_{\mathrm{t}}=\beta_{0}+\beta_{1} \mathrm{LnLA}_{\mathrm{t}}+\beta_{2} \mathrm{MS}_{\mathrm{t}}+\beta_{3} \mathrm{LR}_{\mathrm{t}}+\beta_{4} \mathrm{INF}_{\mathrm{t}}+\mu_{\mathrm{t}}$ $-(3.6)$
NPI= National poverty index used as a proxy for poverty rate LnLA = Loans and advances of microfinance banks MS = Money supply measures as percentage of GDP

$\mathrm{LR}=$ Lending interest rate

$\mathrm{INF}=$ Inflation rate

$\beta_{0}=$ Constant

$\beta_{1}-\beta_{4}=$ Estimation parameters

$\mu_{\mathrm{t}}=$ Stochastic error term incorporated in any regression model based on the classical assumption of a linear regression model to account for variables omitted in the model

Ln = Natural logarithm of the variables used to smoothen possible scholastic effect from variables at level.

$\mathrm{t}=$ Time period

It is expected that $\beta_{1}>0, \beta_{2}>0, \beta_{3}>0, \beta_{4}>0$. However, if the estimates of the parameters turn up with signs or size not conforming to economic theory, they would be rejected, unless there is a good reason to believe that in the particular instance, the principles of economic theory do not hold.

\subsection{Method of Data Analysis}

The estimation method used in this study was in three procedures. The first estimation procedure examines the unit root level of the series used in the investigation. It enables the study to determine the integrated order of the data series through the application of the Augmented Dickey-Fuller (ADF) unit root test. The second estimation procedure will be theory of co-integration which has been developed to eliminate the problem of spurious correlation often associated with non-stationary macroeconomic time series data. According Mill (1990), co-integration establishes the link between integrated processes and the concept of steady state equilibrium. The third estimation procedure involved using error correction model (ECM) to investigate the short run dynamics and long run equilibrium relationship among the data series. The application of ECM is necessary because, it is used to correct temporary short run deviation of a series within long run equilibrium relationship.

The scope will be from 1981 - 2017 to ensure robustness of empirical results as the previous studies ended in 2016. The secondary and time-series data were collected from World Bank national accounts data, OECD National Accounts data files 2017 and Central Bank of Nigeria (CBN Statistical Bulletin, 2017). The relevant variables sourced include Commercial bank deposit used as a proxy for financial inclusion (FI), national poverty index (NPI), loans and advances of microfinance banks (LA), money supply measures as percentage of GDP (MS), lending interest rate (LR) and inflation rate (INF) for the period 1981 to 2017.

\subsection{RESULTS AND DISCUSSION}

\subsection{Unit Roots Test Result}

Where; 
International Journal of Academic Accounting, Finance \& Management Research (IJAAFMR)

ISSN: 2000-008X

Vol. 3 Issue 5, May - 2019, Pages: 1-15

The knowledge of the time series properties of the variables of interest is important in order to obviate the possibilities of spurious regression. This was implemented using the conventional - Augmented Dickey-Fuller (ADF) unit root

Table 4.1: Abridged Presentation of Augmented Dickey-Fuller (ADF) Test for the models respectively

\begin{tabular}{|c|c|c|c|c|c|c|c|c|c|c|c|}
\hline \multicolumn{6}{|c|}{ Model I } & \multicolumn{6}{|c|}{ Model II } \\
\hline \multirow{2}{*}{$\begin{array}{l}\text { Variabl } \\
\text { es }\end{array}$} & \multirow{2}{*}{$\begin{array}{l}\text { ADF- } \\
\text { Statistic }\end{array}$} & \multicolumn{3}{|c|}{ Critical Value } & \multirow{2}{*}{$\begin{array}{l}\text { Order of } \\
\text { Integrati } \\
\text { on }\end{array}$} & \multirow{2}{*}{$\begin{array}{l}\text { Variabl } \\
\text { es }\end{array}$} & \multirow{2}{*}{$\begin{array}{l}\text { ADF- } \\
\text { Statistic }\end{array}$} & \multicolumn{3}{|c|}{ Critical Value } & \multirow{2}{*}{$\begin{array}{l}\text { Order of } \\
\text { Integrati } \\
\text { on }\end{array}$} \\
\hline & & $1 \%$ & $5 \%$ & $10 \%$ & & & & $1 \%$ & $5 \%$ & $10 \%$ & \\
\hline LnFI & $\begin{array}{l}- \\
4.52216 \\
9\end{array}$ & $\begin{array}{l}- \\
3.63290 \\
0\end{array}$ & $\begin{array}{l}- \\
2.94840 \\
4\end{array}$ & $\begin{array}{l}- \\
2.61287 \\
4\end{array}$ & $1(1)$ & NPI & $\begin{array}{l}- \\
6.13624 \\
1\end{array}$ & $\begin{array}{l}- \\
3.63290 \\
0\end{array}$ & $\begin{array}{l}- \\
2.94840 \\
4\end{array}$ & $\begin{array}{l}- \\
2.61287 \\
4\end{array}$ & $1(1)$ \\
\hline LnLA & $\begin{array}{l}- \\
5.47729 \\
2\end{array}$ & $\begin{array}{l}-\overline{3} \\
3.64634 \\
2\end{array}$ & $\begin{array}{l}- \\
2.95402 \\
1\end{array}$ & $\begin{array}{l}- \\
2.61581 \\
7\end{array}$ & 1(1) & LnLA & $\begin{array}{l}- \\
5.47729 \\
2 \\
\end{array}$ & $\begin{array}{l}- \\
3.64634 \\
2\end{array}$ & $\begin{array}{l}- \\
2.95402 \\
1\end{array}$ & $\begin{array}{l}- \\
2.61581 \\
7\end{array}$ & 1(1) \\
\hline MS & $\begin{array}{l}- \\
5.61837 \\
1\end{array}$ & $\begin{array}{l}- \\
3.63290 \\
0\end{array}$ & $\begin{array}{l}- \\
2.94840 \\
4\end{array}$ & $\begin{array}{l}- \\
2.61287 \\
4\end{array}$ & $1(1)$ & MS & $\begin{array}{l}- \\
5.61837 \\
1\end{array}$ & $\begin{array}{l}- \\
3.63290 \\
0\end{array}$ & $\begin{array}{l}- \\
2.94840 \\
4\end{array}$ & $\begin{array}{l}- \\
2.61287 \\
4\end{array}$ & $1(1)$ \\
\hline LR & $\begin{array}{l}- \\
5.90470 \\
7\end{array}$ & $\begin{array}{l}- \\
3.63940 \\
7\end{array}$ & $\begin{array}{l}- \\
2.95112 \\
5\end{array}$ & $\begin{array}{l}- \\
2.61430 \\
0\end{array}$ & $1(1)$ & LR & $\begin{array}{l}- \\
5.90470 \\
7\end{array}$ & $\begin{array}{l}- \\
3.63940 \\
7\end{array}$ & $\begin{array}{l}- \\
2.95112 \\
5\end{array}$ & $\begin{array}{l}- \\
2.61430 \\
0\end{array}$ & $1(1)$ \\
\hline INF & $\begin{array}{l}- \\
5.52600 \\
4\end{array}$ & $\begin{array}{l}- \\
3.63290 \\
0\end{array}$ & $\begin{array}{l} \\
2.94840 \\
4\end{array}$ & $\begin{array}{l}- \\
2.61287 \\
4\end{array}$ & $1(1)$ & INF & $\begin{array}{l}- \\
5.52600 \\
4\end{array}$ & $\begin{array}{l}- \\
3.63290 \\
0\end{array}$ & $\begin{array}{l}- \\
2.94840 \\
4\end{array}$ & $\begin{array}{l}- \\
2.61287 \\
4\end{array}$ & $1(1)$ \\
\hline
\end{tabular}

Source: Author's Compilation with the use of E-views 9 Output

The test results for ADF in the both models showed that commercial bank deposit used as a proxy for financial inclusion (LnFI), loans and advances of microfinance banks (LnLA), money supply measures as percentage of GDP (MS), lending interest rate (LR), inflation rate (INF) and national poverty index used as a proxy for poverty rate (LnNPI) were not stationary at levels but were significant at first difference. Hence, by taking their first difference they became stationary. The next step after finding out the order of integration is to establish whether the non-stationary variables could be co-integrated. The co-integration of two time series suggests that there is a long-run or equilibrium relationship between them.

Table 4.2: Abridged Presentation of Co-integration Test Results for the Models

\begin{tabular}{|c|c|c|c|c|c|c|c|c|c|}
\hline \multicolumn{5}{|c|}{ Model I } & \multicolumn{5}{|c|}{ Model II } \\
\hline $\begin{array}{l}\text { Hypothesized } \\
\text { No. of CE(s) }\end{array}$ & Eigenvalue & $\begin{array}{l}\text { Trace } \\
\text { Statistic }\end{array}$ & $\begin{array}{l}\text { Critical } \\
\text { Value } \\
0.05\end{array}$ & Prob.** & $\begin{array}{l}\text { Hypothesized } \\
\text { No. of CE(s) }\end{array}$ & Eigenvalue & $\begin{array}{l}\text { Trace } \\
\text { Statistic }\end{array}$ & $\begin{array}{l}\text { Critical } \\
\text { Value } \\
0.05\end{array}$ & Prob.** \\
\hline \multicolumn{5}{|c|}{ Exogenous series: LnFI } & \multicolumn{5}{|c|}{ Exogenous series: NPI } \\
\hline None* & 0.886459 & 204.1348 & 69.81889 & 0.0000 & None* & 0.869016 & 155.1628 & 69.81889 & 0.0000 \\
\hline At most $1 *$ & 0.859759 & 132.3403 & 47.85613 & 0.0000 & At most $1^{*}$ & 0.613088 & 88.08435 & 47.85613 & 0.0000 \\
\hline At most $2 *$ & 0.542869 & 67.51535 & 29.79707 & 0.0000 & At most 2* & 0.593595 & 56.74892 & 29.79707 & 0.0000 \\
\hline At most $3^{*}$ & 0.503802 & 41.68343 & 15.49471 & 0.0000 & At most 3* & 0.436768 & 27.03558 & 15.49471 & 0.0006 \\
\hline At most $4^{*}$ & 0.430134 & 18.55769 & 3.841466 & 0.0000 & At most 4* & 0.217448 & 8.091451 & 3.841466 & 0.0045 \\
\hline \multicolumn{5}{|c|}{$\begin{array}{l}\text { Trace test indicates } 5 \text { co-integrating eqn(s) at the } 0.05 \text { level } \\
* \text { denotes rejection of the hypothesis at the } 0.05 \text { level }\end{array}$} & \multicolumn{5}{|c|}{$\begin{array}{l}\text { Trace test indicates } 5 \text { co-integrating eqn(s) at the } 0.05 \text { level } \\
* \text { denotes rejection of the hypothesis at the } 0.05 \text { level }\end{array}$} \\
\hline
\end{tabular}

test. For convenience, table 4.1 is a tabular presentation of the abridged unit-root tests carried out on the variables.

\subsection{Johansen Co-Integration Test}

A necessary but not sufficient condition for co-integrating test is that each of the variables be integrated of the same order. The Johansen co-integration test uses two statistics tests namely; the trace test and the likelihood eigenvalue test. The first row in each of the table test the hypotheses of no co-integrating relation, the second row test the hypothesis of one co-integrating relation and so on, against the alternative of full rank of co-integration. The results are presented in table 4.2 below. 
International Journal of Academic Accounting, Finance \& Management Research (IJAAFMR)

ISSN: 2000-008X

Vol. 3 Issue 5, May - 2019, Pages: 1-15

\begin{tabular}{|c|c|c|c|c|c|c|c|c|c|}
\hline \multicolumn{5}{|c|}{ **Mackinnon-Haug-Michelis (1999) p-values } & \multicolumn{5}{|c|}{ **Mackinnon-Haug-Michelis (1999) p-values } \\
\hline \multirow{2}{*}{$\begin{array}{l}\text { Unrestricted } \\
\text { Eigenvalue) } \\
\text { None }^{*}\end{array}$} & \multicolumn{2}{|c|}{ Cointegration Rank } & \multicolumn{2}{|c|}{ Test (Maximum } & $\begin{array}{l}\text { Unrestricted } \\
\text { Eigenvalue) }\end{array}$ & \multicolumn{2}{|c|}{ Cointegration Rank } & Test & \\
\hline & 0.886459 & 71.79447 & 33.87687 & 0.00 & None* & 69016 & 67.07850 & 33.87687 & \\
\hline At most $1 *$ & 759 & 4.82496 & 27.58434 & & & & 31.33543 & 27.58434 & \\
\hline At most $2 *$ & 869 & 25.83191 & 21.13 & & & & 29.71334 & 21.1 & 024 \\
\hline At most $3 *$ & 802 & 23.12574 & 14.26460 & & $3^{*}$ & & 18.94413 & 14.26 & 85 \\
\hline At most $4 *$ & 0.430134 & 18.55769 & 3.841466 & 0.0000 & At most $4^{*}$ & 0.217448 & 8.091451 & 3.841466 & 0.0045 \\
\hline \multicolumn{5}{|c|}{$\begin{array}{l}\text { Max-eigenvalue test indicates } 5 \text { cointegrating eqn(s) at the } 0.05 \\
\text { level } \\
* \text { denotes rejection of the hypothesis at the } 0.05 \text { level } \\
* * \text { MacKinnon-Haug-Michelis (1999) p-values }\end{array}$} & \multicolumn{5}{|c|}{$\begin{array}{l}\text { Max-eigenvalue test indicates } 5 \text { cointegrating eqn(s) at the } 0.05 \\
\text { level } \\
* \text { denotes rejection of the hypothesis at the } 0.05 \text { level } \\
* * \text { MacKinnon-Haug-Michelis (1999) p-values }\end{array}$} \\
\hline
\end{tabular}

Source: Author's Compilation with the use of E-views 9 Output

From table 4.2 above, both the Trace statistic and Max-Eigen statistic reported that there was presence of five (5) co-integration equations among the variables in both models. This means that a long run interaction existed among these relevant variables. Both the Trace statistic and Max-Eigen statistic were greater than their respective critical values and significant at 5 percent level. As such, it was concluded that a long run equilibrium relationship rightly existed among these variables of interest used in the study.
Table 4.4 below shows the result of the normalized cointegration coefficients of the variables for the case of a cointegrated equation with respect to the standard error and t-statistic result associated with each variable. The value of the t-statistic is used to indicate the significance or otherwise of the independent variable in the long run. Generally using the rule of thumb, if the t-statistics is 2 or greater than two, the variable is considered to be significant but if otherwise, it is insignificant.

\subsection{Long Run Estimates using Normalized Cointegration}

Table 4.3: Abridged Presentation of Normalized Co-integrating test results for the Models

\begin{tabular}{|l|l|l|l|l|}
\hline \multicolumn{5}{|c|}{ Model I } \\
\hline Normalized Cointegrating Coefficients (Standard Error in Parentheses) \\
\hline $\mathrm{D}(\mathrm{LnFI}, 2)$ & $\mathrm{D}(\mathrm{LnLA}, 2)$ & $\mathrm{D}(\mathrm{MS}, 2)$ & $\mathrm{D}(\mathrm{LR}, 2)$ & $\mathrm{D}(\mathrm{INF}, 2)$ \\
\hline \multirow{3}{*}{1.000000} & 3.355535 & -4.223052 & 4.821922 & 0.314422 \\
\cline { 2 - 5 } & $(1.60710)$ & $(1.00994)$ & $(0.47576)$ & $(0.11981)$ \\
\cline { 2 - 5 } & {$[2.08794]^{* *}$} & {$[4.18148]^{* *}$} & {$[10.1351]^{* *}$} & {$[2.62433]^{* *}$} \\
\hline $\mathrm{D}(\mathrm{NPI}, 2)$ & $\mathrm{D}(\mathrm{LnLA}, 2)$ & $\mathrm{D}(\mathrm{MS}, 2)$ & $\mathrm{D}(\mathrm{LR}, 2)$ & $\mathrm{D}(\mathrm{INF}, 2)$ \\
\hline \multirow{2}{*}{1.000000} & 2.390265 & -1.436820 & 3.191328 & 0.098208 \\
\cline { 2 - 5 } & $(1.20485)$ & $(0.73231)$ & $(0.32026)$ & $(0.05464)$ \\
\cline { 2 - 5 } & {$[1.98386]$} & {$[1.96203]$} & {$[9.96480]^{* *}$} & {$[1.79736]$} \\
\hline
\end{tabular}

Source: Author's Compilation with the use of E-views 9 Output

Note: Standard error and t-statistics are stated in parenthesis () and [ ] respectively.

** indicate significance of parameter employing standard error test

Going through the results obtained from model one, the coefficient estimate of loans and advances of microfinance banks (LnLA), lending interest rate (LR) and inflation rate (INF) are positive and statistically significant effect with commercial bank deposit used as a proxy for financial inclusion in the long run. Hence we observed that, a $1 \%$ increase in LnLA, LR and INF will bring about 335\%, 482\% and $31.4 \%$ increase in financial inclusion in the long run in Nigeria. While coefficient of money supply measures as percentage of GDP (MS) is negative but statistically significant with financial inclusion in Nigeria.

In the model two (2), the result of the normalized cointegrated relationship reveals that loans and advances of microfinance banks (LnLA) and inflation rate (INF) are positive and statistically significant effect with national poverty index used as a proxy for poverty in the long run. While lending interest rate (LR) has positive and significant effect on national poverty index used as a proxy for poverty. Hence we observed that, a $1 \%$ increase in LnLA, LR and INF on the average will bring about $239 \% 319 \%$ and $9.82 \%$ increases in poverty in the long run in Nigeria. Again, the coefficient estimate of money supply measures as percentage of GDP (MS) is negative but statistically insignificant effect on national poverty index used as a proxy for poverty in the long run. Hence we observed that, a $1 \%$ increase in money supply will bring about $143.6 \%$ decreases in national poverty index in the long run in Nigeria. We moved on to the ECM which will help us to see the short -run dynamics of the model. ECM will enable us determine the speed of adjustment from short - run to long - run equilibrium.

\subsection{Error Correction Model (ECM)}


International Journal of Academic Accounting, Finance \& Management Research (IJAAFMR)

ISSN: 2000-008X

Vol. 3 Issue 5, May - 2019, Pages: 1-15

Since the variables are cointegrated, the error correlation model is required to construct the dynamic relationship of the model. The purpose of the error correlation model is to indicate the speed of adjustment from short run dynamic to the long run equilibrium state.

Table 4.4 Abridged Presentation of Estimated Error Correction Model Results for the models

\begin{tabular}{|c|c|c|c|c|c|c|c|c|c|}
\hline \multicolumn{5}{|c|}{ Model I } & \multicolumn{5}{|c|}{ Model II } \\
\hline Variable & Coefficient & Std.Error & t-Statistic & Prob. & Variable & Coefficient & Std.Error & t-Statistic & Prob. \\
\hline \multicolumn{5}{|c|}{ Dependent Variable: LnFI } & \multicolumn{5}{|c|}{ Dependent Variable: NPI } \\
\hline $\mathrm{C}$ & 5.645202 & 1.701995 & 3.316815 & $0.0024 *$ & $\mathrm{C}$ & 37.19763 & 2.935591 & 12.67126 & $0.0000^{*}$ \\
\hline LnLA & 0.551371 & 0.186931 & 2.949597 & $0.0061 *$ & LnLA & 1.530050 & 0.332298 & 4.604444 & $0.0001 *$ \\
\hline MS & -0.240536 & 0.093085 & -2.584034 & $0.0149 *$ & MS(-1) & -0.236265 & 0.166365 & -1.420161 & 0.1659 \\
\hline LR & 0.056411 & 0.086580 & 0.651543 & 0.5197 & LR & 0.394477 & 0.150317 & 2.624298 & $0.0135^{*}$ \\
\hline INF & 0.005222 & 0.020961 & 0.249149 & 0.8049 & INF & 0.006240 & 0.037620 & 0.165868 & 0.8694 \\
\hline ECM(-1) & -0.635717 & 0.152121 & -4.179029 & $0.0002 *$ & ECM(-1) & -0.745489 & 0.123035 & -6.059145 & $0.0000^{*}$ \\
\hline \multicolumn{5}{|c|}{ R-squared $=0.538866$} & \multicolumn{5}{|c|}{ R-squared $=0.764391$} \\
\hline \multirow{2}{*}{\multicolumn{5}{|c|}{$\begin{array}{l}\text { Adjusted R-square }=0.462010 \\
S \text { SE of reoression }=1.835041\end{array}$}} & \multicolumn{5}{|c|}{ Adjusted R-square $=0.725123$} \\
\hline & & & & & & ssion $=3.303$ & & & \\
\hline \multicolumn{5}{|c|}{ F-statistics $=7.011393$} & \multicolumn{5}{|c|}{ F-statistics $=19.46597$} \\
\hline \multicolumn{5}{|c|}{ Prob (F-statistics) $=0.000191$} & \multicolumn{5}{|c|}{ Prob (F-statistics) $=0.000000$} \\
\hline \multicolumn{5}{|c|}{ Durbin Watson $=1.509170$} & \multicolumn{5}{|c|}{ Durbin Watson $=1.755421$} \\
\hline
\end{tabular}

Source: Author's Compilation using E-views 9 Output

Note: $*$ denote statistical significance at the $1 \%$ and $5 \%$ level.

Based on table 4.4, the results revealed that, the constant term is positive, even though it does not have any economic meaning; it meets our a priori expectation. Therefore, this shows that regardless of change on the explanatory variables, the commercial bank deposit used as a proxy for financial inclusion and national poverty index used as a proxy for poverty rate will be increased in the study in the respective models. The parameter estimate for loans and advances of microfinance banks (LnLA) in the both models showed that it relates positively with commercial bank deposit used as a proxy for financial inclusion and it's statistically significant. The function thus shows that, one percent increase in the loans and advances of microfinance banks hold other variables constant, will increase the financial inclusion and national poverty index used as a proxy for poverty rate by $55 \%$ and $153 \%$ respectively. Again, the coefficient of money supply (MS) in the both models was found to be negative and statistically significant in the model one. The function thus shows that a one percent change in MS will reduce financial inclusion and national poverty index used as a proxy for poverty rate by $24 \%$ and $23 \%$ respectively in Nigeria. Also, the effect of lending interest rate (LR) has a positive coefficient and statistically significant with poverty in Nigeria in the mode two. The function thus shows that a one percent change in LR lead to $5.64 \%$ and $39.4 \%$ increase in the financial inclusion and national poverty index used as a proxy for poverty rate in Nigeria. Furthermore, the value of regression coefficient of inflation rate in the both model is positive 0.005222 and 0.006240 , demonstrating that if inflation rate goes up by one million; financial inclusion and national poverty index used as a proxy for poverty rate goes up by about $52 \%$ and $0.62 \%$. The impact of inflation on financial inclusion and national poverty index used as a proxy for poverty rate is positive and but statistically insignificant in the models.

The coefficient of determination $\mathrm{R}^{2}$ measures the goodness of fit of the fitted regression line to a set of data. The $\mathrm{R}^{2}$ of the models 0.538866 and 0.764391 shows that the explanatory variables (loans and advances of microfinance banks (LnLA), money supply measures as percentage of GDP (MS), lending interest rate (LR) and inflation rate (INF)) explained $53.8 \%$ and $76.4 \%$ of the total variation in financial inclusion and national poverty index used as a proxy for poverty rate in Nigeria. While about $46.2 \%$ and $23.6 \%$ are accounted for by variables outside the models. Coincidentally, the goodness of fit of the regression remained too low after adjusting for the degree of freedom. The result revealed that, the overall regression model is significant. This is evidenced by the probability of $f$-statistic is 0.000191 and 0.000000 , which is less than $0.05 \%$. The value of Durbin Watson is 1.50 and 1.75 in the models. By implication, there is evidence of positive serial correlation among the explanatory variables in the models. Finally, the coefficient of error correction mechanism (ECM) is negative in the both models. This is in line with economic and econometrics expectations. The error correction mechanism corrects $63.57 \%$ and $74.54 \%$ of the total error that occurs in the model.

\subsection{Diagnostics and Stability Test Results}

It is important to conduct some diagnostic test while building and estimating a model (Davidson \& Mackinnon, 1999). The above estimated error correction model was further subjected to serial correlation, Autoregressive Conditional heteroskedasticity (ARCH), normality of the residual, functional form misspecification and heteroskedasticity test statistics and stability test. The test results are reported in table 4.5 below. 
Table 4.5: Diagnostics Test Result for the Models

\begin{tabular}{|c|c|c|c|}
\hline \multicolumn{4}{|c|}{ Model I } \\
\hline Test & F-statistic & $\begin{array}{l}\text { Degree } \\
\text { Freedom }\end{array}$ & Probability \\
\hline Normality Test (Jarque-Bera Statistics) & 1.111443 & - & 0.573658 \\
\hline Serial Correlation (Breush-Godfrey Serial Correlation LM Test) & 3.706518 & $\mathrm{~F}(2,28)$ & 0.2373 \\
\hline ARCH Test (Autoregressive Heteroskedasticity Test) & 0.035657 & $\mathrm{~F}(1,33)$ & 0.8514 \\
\hline Heteroskedasticity Test (Breush-Pagan-Godfrey) & 1.994461 & $\mathrm{~F}(5,30)$ & 0.1082 \\
\hline Model Specification Test (Ramsey RESET Test) & 0.185357 & $\mathrm{~F}(1,29)$ & 0.6700 \\
\hline \multicolumn{4}{|l|}{ 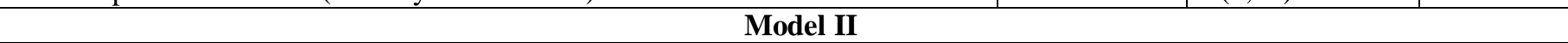 } \\
\hline Normality Test (Jarque-Bera Statistics) & 0.321594 & - & 0.851465 \\
\hline Serial Correlation (Breush-Godfrey Serial Correlation LM Test) & 0.564091 & $\mathrm{~F}(2,23)$ & 0.5766 \\
\hline ARCH Test (Autoregressive Heteroskedasticity Test) & 0.164934 & $\mathrm{~F}(1,31)$ & 0.6874 \\
\hline Heteroskedasticity Test (Breush-Pagan-Godfrey) & 2.137494 & $\mathrm{~F}(8,25)$ & 0.0701 \\
\hline Model Specification Test (Ramsey RESET Test) & 0.003811 & $\mathrm{~F}(1,24)$ & 0.9513 \\
\hline
\end{tabular}

Source: Author's Compilation Using E-views 9 Output

The diagnostic tests showed that the model is free of serial correlation problems, the model has no ARCH effects, the residual is normally distributed, there is no heteroscedasticity problem, and there is no functional form misspecification in the model. This gives us assurance that the results from the model are reliable, efficient and will be suitable for forecasting and policy and decision making. Finally, to inspect the stability of the short run and long run coefficients in the model, CUSUM and CUSUMSQ plots are drawn. Figure 4.1 and 4.3 displays the plot of cumulative sum of recursive residuals in the models while Figure 4.2 and 4.4 displays the plot of cumulative sum of squares of recursive residuals in the models. Both CUSUM and CUSUMSQ are within the critical bounds of 5 percent. Therefore, it can be safely inferred that the model is structurally stable.

Figure 4.1: Plot of Cumulative Sum (CUSUM) of Recursive Residuals for model one

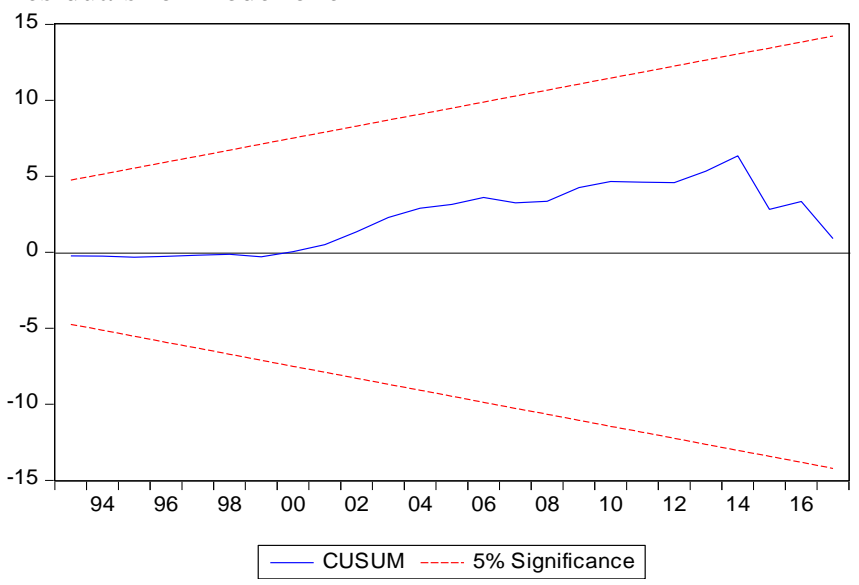

Figure 4.2: Plot of Cumulative Sum of Squares (CUSUMQ) of Recursive Residuals for model one

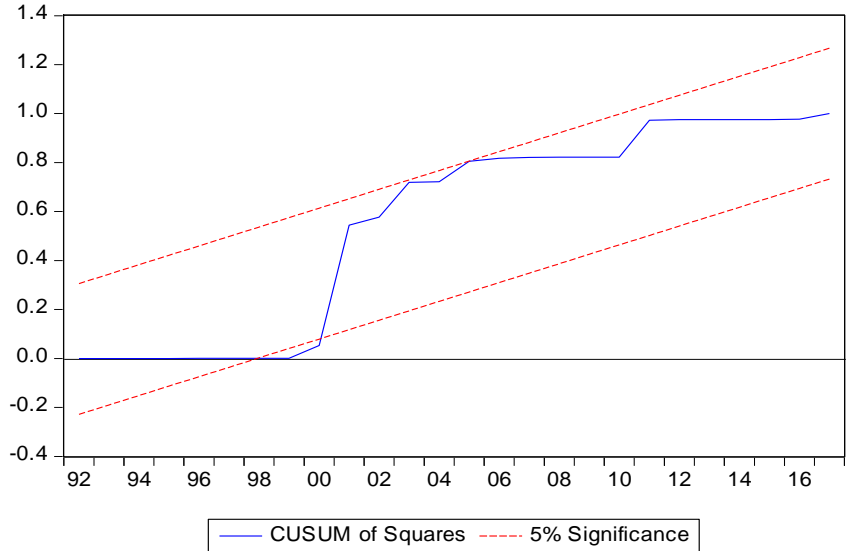

Figure 4.3: Plot of Cumulative Sum (CUSUM) of Recursive Residuals for model two

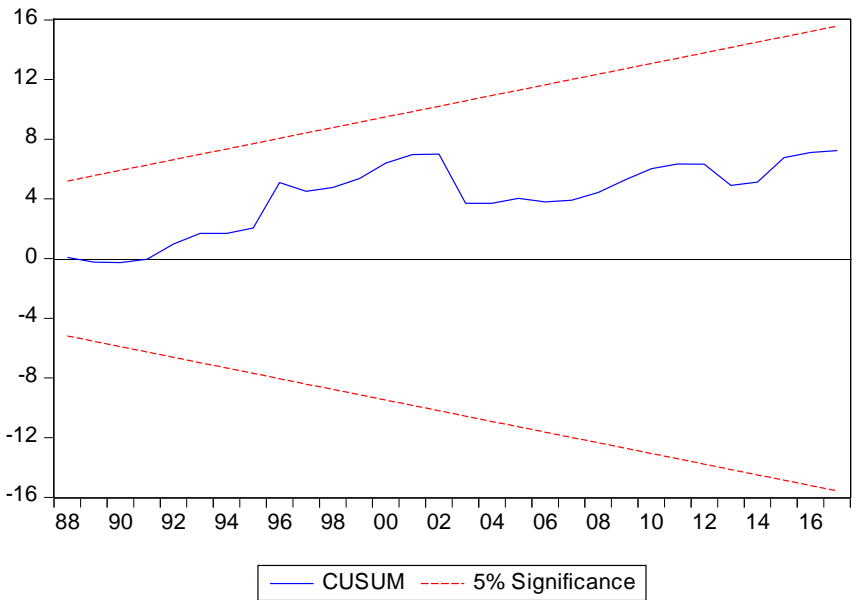


Figure 4.4: Plot of Cumulative Sum of Squares (CUSUMQ) of Recursive Residuals for model two

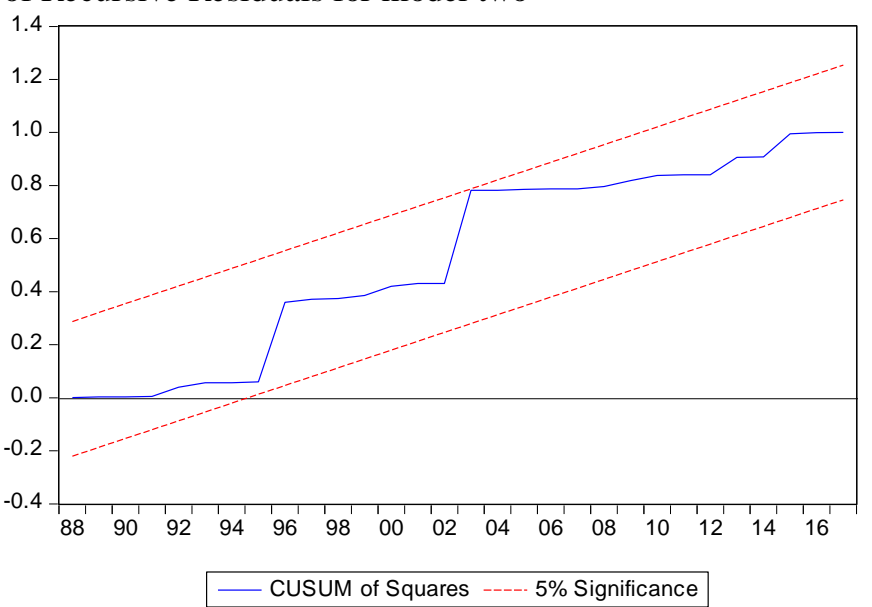

\subsection{Test of Hypotheses}

The first model was constructed to test the null hypothesis that microfinance has no significant effect on financial inclusion in Nigeria. Judging from the estimated t-statistic value of loans and advances of microfinance banks is 2.949597 with p-value of 0.0024 ; it indicates that it is statistically significant at 5\% level. The research rejects the alternative hypothesis and concludes that microfinance has positive significant effect on financial inclusion in Nigeria. This finding is in line CBN objectives for the establishment of microfinance banks.

The effect of lending interest rate in the short-run has a positive but has no significant with financial inclusion in the model one while it is statistically significant with poverty in Nigeria in the mode two. The positive lending interest rate has a statistically significant effect on the level of financial inclusion and national poverty index used as a proxy for poverty rate in the long run in the models.

The purpose of the second model is to test the null hypothesis that states microfinance is not really a tool to fight against poverty in Nigeria. Judging from the estimated $\mathrm{t}$-statistic value of loans and advances of microfinance banks is 4.604444 with $\mathrm{p}$-value of 0.0001 ; it indicates that it is statistically significant at 5\% level. The research rejects the alternative hypothesis and concludes that microfinance has really a tool to fight against poverty in Nigeria.

\subsection{CONCLUSION AND RECOMMENDATION}

Microfinance is not a panacea to all problems of poverty. It is considered as a vital tool to break the vicious circle of poverty that characterized by low income, low savings and low investment. In order to generate higher incomes, savings and more investment, there is need to inject capital in the form of microfinance. However, this study examined the microfinance and financial inclusion nexus in Nigeria from 1981 to 2017. The Augmented Dickey-Fuller (ADF) test, co- integration test and Error Correction Model (ECM), as well as diagnostics and stability test were employed in the analysis. The respective test shows that all the variables used in the models were stationary at first differencing respectively. Also, the co-integration test carried out indicates that loans and advances of microfinance banks, money supply measures as percentage of GDP, lending interest rate and inflation rate and financial inclusion and national poverty index used as a proxy for poverty rate in Nigeria have a long run relationship. The outcome of the Johansen co- integration test using both trace and max-eigen test statistics reveals the presence of long-run relationship among the variables at level of significance, which support the rejection of null and acceptance of alternate hypothesis that there is co-integration.

The research findings revealed that microfinance has positive significant effect on financial inclusion in Nigeria in the short-run and long-run. This finding is in line CBN objectives for the establishment of microfinance banks. In the short-run, the effect of lending interest rate has a positive but has no significant with financial inclusion in the model one while it is statistically significant with poverty in Nigeria in the mode two. The positive lending interest rate has a statistically significant effect on the level of financial inclusion and national poverty index used as a proxy for poverty rate in the long run in the models. Therefore, this study has established that microfinance, as well as lending interest rates, is a significant driver of financial inclusion in Nigeria. Microfinance heightened driver to increase financial inclusion in Nigeria. In other hand, microfinance represents a vehicle for the promotion of financial inclusion in Nigeria and should remain at the core of the pursuit of financial participation across all income levels. Also, the research also found that microfinance has really a tool to fight against poverty in Nigeria in the short-run, while it's not really a tool to fight against poverty in the long-run in Nigeria.

The study policy recommendation therefore centres on the need Government agency and regulatory authority policies and practices play a key role in making micro-credit available to the economically-active poor people who are not being served by the formal financial sector. Apart from monitoring lending rates, the government needs to establish frameworks to prevent undercapitalization, fraudulent practices, and unwarranted interference from bank board members.

\section{REFERENCES}

1. Adeola, O. \& Olaniyi, E. (2017). The Impact of Microfinance on Financial Inclusion in Nigeria

2. The Journal of Developing Areas, 51(4): 193-206.

3. Ananwude, A. C., Anyanwu, F. A., \& Andrew, I. N. (2018). Financial Inclusion: Nigeria's Microfinance 
Model Effect Assessment on Women Empowerment. European Journal of Human Resource Management Studies, 1(2): 55-77.

4. Atiase, V. Wang, Y. \& Mahmood, S. (2019). FNGOs and Financial Inclusion: Investigating the Impact of Microcredit on Employment Growth in Ghana. The International Journal of Entrepreneurship and Innovation, 20(2): 90-106.

5. Beck, T., Demirgüç-Kunt, A., \& Honohan, P. (2009). Access to Financial Services: Measurement, Impact, and Policies. The World Bank Research Observer.

6. Beck, T., \& Demirgüç-Kunt, A. (2008). Access to Finance: An Unfinished Agenda. The World Bank Economic Review, 22(3): 383-396.

7. Boot, A. W., \& Thakor, A. V. (1993). Self-interested Bank Regulation. The American Economic Review,83(2): 206-212.

8. Brealey, R., Leland, H. E., \& Pyle, D. H. (1977). Informational Asymmetries, Financial Structure, and Financial Intermediation. The Journal of Finance, 32(2): 371-387.

9. Brunnermeier, M. K., Crockett, A., Goodhart, C. A., Persaud, A., \& Shin, H. S. (2009). The Fundamental Principles of Financial Regulation. International Center for Monetary and Banking Studies (ICMB). Retrieved from: https://web.actuaries.ie/sites/default/files/ermresources/The_fundamental_principles_of_financial _regulation.pdf.

10. Campbell, T. S., \& Kracaw, W. A. (1982). Information Production, Market Signalling, and the Theory of Financial Intermediation: A reply. The Journal of Finance, 37(4): 1097-1099.

11. Center for Financial Inclusion (2013). Microfinance vs. Financial Inclusion: What's the Difference?

12. Collins, D., Morduch, J., Rutherford, S., \& Ruthven, O. (2009). Portfolios of the Poor: How the World's Poor Live on \$2 a Day. New Jersey, NJ: Princeton University Press.

13. Davidson, R. \& MacKinnon, J.G. (1999). The Size Distortion of Bootstrap Tests. Econometric Theory,15(4): 361-376.

14. Demirguc-Kunt,A., Klapper, L. \& Singer, D. (2017). Financial Inclusion and Inclusive Growth : A Review of Recent Empirical Evidence. Policy Research Working Paper Series 8040, The World Bank.

15. Dwivedi, S. (2013). Microfinance - one of the Key Drivers of Financial Inclusion. A Research Paper.

16. Ene, E.E. \& Inemesit, U.A. (2015). Impact of Microfinance in Promoting Financial Inclusion in
Nigeria. Journal of Business Theory and Practice, 3(2):139-158.

17. Ezeanyeji, C.I. \& Ozughalu, U. M. (2014). Conceptual and Theoretical Issues in Poverty, and a Reflection on the Poverty and Competitive Situation in Nigeria. International Journal of Economics, Commerce and Management, 2(11):1-16.

18. Greenbaum, S. I., Thakor, A. V., \& Boot, A. (2015). Contemporary Financial Intermediation (3rd ed.). California, CA: Academic Press.

19. Hannig, A. \& Jansen, S. (2010). Financial Inclusion and Financial Stability': Current Policy Issues.

20. Ibeachu, E. H. (2010). Comparative Analysis of Financial Inclusion: A Study of Nigeria and the UK, Master Degree Thesis in International Business Leeds Metropolitan University Faculty of Business \& Law.

21. Johnston, D., \& Morduch, J. (2008). The Unbanked: Evidence from Indonesia. The World Bank Economic Review, 22(3): 517-537.

22. Kwakye, J. K. (2012). Financial Intermediation and the Cost of Credit in Ghana. Accra, Ghana: The Institute of Economic Affairs (IEA). Retrieved from Retrieved from: http://ieagh.org/wpcontent/uploads/2014/08/Monograph-No.-36Financialintermediation-and-the-cost-of-credit-in-Ghana.pdf.

23. Mills, T.C. (1990). Time Series Techniques for Economists. Cambridge University.

24. Olaniyi, E. (2017). Back to the Land: The Impact of Financial Inclusion on Agriculture in Nigeria. Iran. Econ. Rev, 21(4): 885-903.

25. Osamwonyi, I.O. \& Obayagbona, J. (2012). The Role of Microfinance Banking in the Development of the Nigerian Economy. Finance \& Banking Review, 6(1\&2):46-66.

26. Roadwan, I. (2012). The Potentials of Public-Private Partnerships in Microfinance Delivery. A paper presented at International Microfinance Conference Abuja, Nigeria on January 2008.

27. Sharpe, S. A. (1990). Asymmetric Information, Bank Lending, and Implicit Contracts: A Stylized Model of Customer Relationships. The Journal of Finance, 45(4): 1069-1087.

28. Scholes, M., Benston, G. J., \& Smith, C. W. (1976). A Transactions Cost Approach to the Theory of Financial Intermediation. The Journal of Finance, 31(2): 215-231.

29. Scholtens, B., \& van Wensveen, D. (2003). The Theory of Financial Intermediation (SUERF Studies: 2003/1). Vienna, Austra: SUERF - The European Money and Finance Forum. Retrieved from 
International Journal of Academic Accounting, Finance \& Management Research (IJAAFMR) ISSN: 2000-008X

Vol. 3 Issue 5, May - 2019, Pages: 1-15

https://pdfs.semanticscholar.org/8636/9b327b9d9a2 42562a605dc1e85c38c4fa665.pdf.

30. Usifoh, K. S. \& Ezeanyeji, C.I. (2017). Impact of Microfinance Banks on Poverty Alleviation and Economic Growth in Nigeria. NG - Journal of Social Development, 6(5):22-34.

31. World Bank. (2015). World Development Indicators. 